\title{
Gebelik ve siklus dönemlerinin belirlenmesi amacıyla ratlarda vaginal sitolojinin kullanılması
}

\author{
Gökhan OBA ${ }^{1}$, Selim ASLAN ${ }^{2}$, Mustafa KAYMAZ ${ }^{3}$

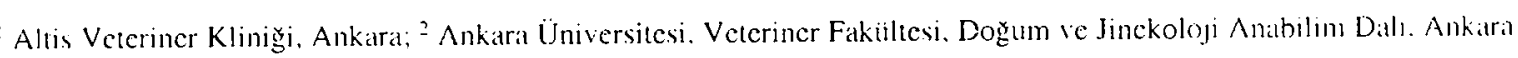

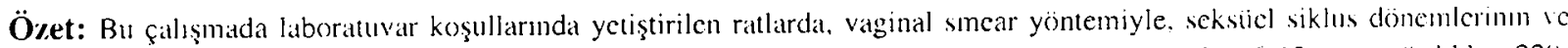

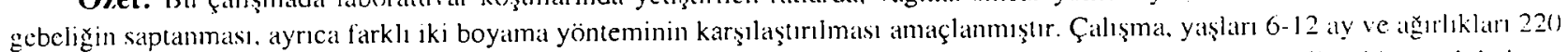

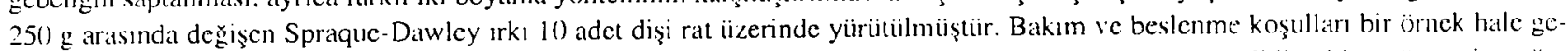
tirilmişir. Alt1-12 saatlik aralıklarla. tum materyalden alman toplam 180 adet örnck. Papanicolaou ve toulidine bluc yöntemine göre

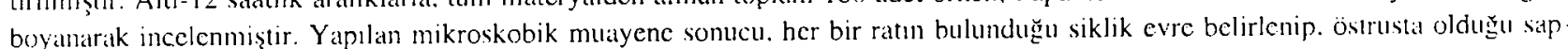
timan dişilerin kafeslerine crkek bırakıımışır. Elde edilen vaginal smear'lerın siklik evrelere görc dağllım \% 13.4 proostrus ( $n=12$ )

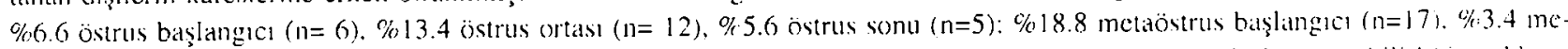
taöstrus sonu $(n=3)$; \% 7.7 diöstrus $(n=7)$ ve \%31.1 gebclik $(n=28)$ dönemi șeklinde olmuşur. Hücrelerin tanulabilirlıği: nukleus. çeper ve sitoplazmann boya alma durumu: asidofili: bazofili: keratinizasyon; mukus ve lökositlerin seçilebilirliğ gibi hiceresel i)zel liklerin belirlenmesi ve preparatlarm kalıcll ğ kriterleri gö. önime alınarak yapılan degerlendirmede, toluidine bluc yönteminin kul lamlabilir bunun yanında Papanicolaou boyama yönteminin isc ideal sonuçlar verdiģi saptanmınşır. Ayrıcal. siklus dönemlerinin latnınmasında. toluidine blue yönteminin her örnekte yeterli olmadı̨̆. Papanicolaou ile hazırlanan smearlerde isc farthlı hücre liplerinin

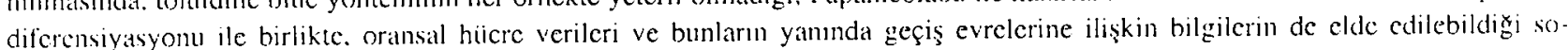

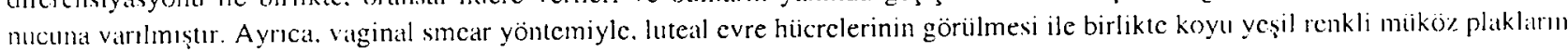
varlığına dayanarak. gebeliộe ilișkin fikir yürïtmede etkili olabileceği de belirlenmiștir.
\end{abstract}

Anahtar kelimeler: Gebelik. Papanicolaou, rat, toluidinc bluc, vaginal smear

\section{The determination of rats cyclic periods and pregnancy by means of vaginal smear method using two staining techniques}

Summary: In the present study, the purpose is to investigate whether sextal periods and pregnancy can be determined by means of vaginal sincar in rats bred under laboratory conditions. This study was performed on 10 female Spraque-Dawley rats weighing between 220-250 $\mathrm{g}$ and at the age of 6-12 months. The welfare conditions of the rats were became the same. Total 180 ) vaginal smear simples taken from the all rats at an interval of $6-12$ hours, were assessed according to staining procedure of Papanicolaou and toluidine blue. Each rat's cyclic phase was determined by microscopic examinations and a male was placed to the citec of the rats in eostrus period. The proportion of the vaginal smear with regard to cyclic phases was found as $13.4 \%$ pro-oestrus $(n=12): 0.6 \%$ cirly ocstrus $(n=6) .13 .4 \%$ mid-ocstrus $(n=12), 5.6 \%$ late ocstrus $(n=5)$; $18.8 \%$ carly metocstrus $(n=3) .7 .7 \%$ diocstrus $(11=7)$ and $31.1 \%$ pregnancy $(n=28)$. According to the assesment carricd out depending on the obscrvation of cell features such ats cell's cleirnty. stalining quality of nucleus. cell membrane and cytoplasm, acidophily, basophily, kcratinization, clearity of mucus and leukocyles and also the persistency of preparations, it has been found that toluidine blue method could be used. but Papanicoliou procedure gives more ideal results. In addition to the differences in determining the features mentioned above. it has been concluded that tolutine bluc method does not give sufficient results for cach sample in defining cyclic phases. As for smears staincd with Papanicolaon procedure. logether with the differentiation of different cell types, proportional cell datit and knowledge about transition peried could be oblained. Besides. vaginal smear can give a strong idea on the presence of pregnancy depending on the observaltion of lutcal phase cells and dark green mucous plaques.

Key words: Papanicolaou, pregnancy, rat, toluidine blue, vaginal smear

\section{Giriş}

Bilimsel anlamda yapılacak çalışmaların güvenilebilir olabilmesi için kullanılacak dency hayvanının bakım ve beslemesinin bir örnek olması gerekmekte vc bu nedenle seksiiel siklus evrelerinin ve gebeliğin saptanması önem taşımaktadır.

Ratlar puberta başlangıcından yaşhı̆ğa kadar siklik aktive gösteren ve mevsime bağlı olmayan poliöstrik hayvanlardır $(2,8,10)$
Ratlarda vagina epiteli, prö̈strus döncminde 2.8 , östrus döneminde 7-11, metaöstrus döneminde 5-9 hücre katı içerir, diöstrus döneminde ise katlam sayısı yeniden 10 'a yüksclir $(15,20)$.

Proöstrus başlangıcında, vaginal sitolojide. en basskın hücre tipi intermediyer hücredir. suiperfisial ve parabazal hücreler a\% sayldadır. Kornifiye epitel buicreleri ender olarak görüilür. Süperfisial hücreler. dönenin so nunda baskın görünüme ulaşacak olan korniliyc huic 
relerle yer değiştirene kadar artar. Geç proöstrusta smear'de karyopiknotik ve kornifiye hücreler baskındır (18).

Sitolojik olarak östrus evresi, nukleuslu cpitel huicreleriyle kornifiye epitel hücrelerin bulunması ve lökosit sayısının göreceli varlığına göre tanımlanır (16).

Östrus başlangıcında, smear'de kornifiye olmuş hücreler artış gösterir. Lökositler bu dönemde görülebilir. Artan östrogen duizeyine karşı oluşan cevap, kornifiye hücrclerin sayısında artış biçiminde kendini gösterdiğinden, bu dönemde süperfisial hücrelerin diğer cpitel huicrelere oranı saptanabilir. Östrogenin etkisinde intermediyer hücreler prekornifikasyona uğrar; bu durumda süperfisial hücre karaktcri, sitoplazmanın cozinofilik hale gelmesi ve nuklcusun büzüşmesi ile kendini belli eder. Dönemin ortalarında, \%75 oranında çekirdekli, \%25 oraninda ise kornifiye hücre bulunur (19).

Mctaöstrusta smear'de büyük düz çekirdekli hücrelerin tekrar ortaya çıkışı göruilür. Östrusta vaginal epitelin süperfisial tabakasında kornifiyc hücreler mevcut iken, bunların dökülmesi ile metaöstrusta lökositlerin yayılımı görüilür. Tüm kornifiye hücreler döküldükçe, derin tabakalardan gelen epitel hücrcler görülür ve polimorf nüklecr lökositler smear'de fark edilir. Ovaryum steroidlerinin yarattığı etkinin hızla diişmesi nedeni ile smear tipik olarak atrofik hale gelir, epitel hücre populasyonu parabazal tipe dönüşür ve zeminde değişken miktarda mukus meydana gelir $(8,11)$.

Gebe hayvanlarda ve progesteron enjekte edilmiş steril ratlarda smear'de belirgin bir zemin oluşturan polimorf nükleer lökositler ve mukus gözlenir. Gebelikte intermediyer hücrelerin bulunuşunun karckteristik bir örnek olduğu açıklannıştır. Metaöstrus ve diöstrusta vagina duvarı nemlidir (6). Gebelik ya da yalancı gebelik sırasında smear'de lökosit invazyonu tipiktir $(2,8)$.

Ejekulasyondan 10 dakika sonra spermanın bir bölümü, 40 dakika sonra tamamı koagüle olarak vaginal plak oluşumu gerçekleşir (4).

Vaginal sitolojide, değerlendirilebilir nitclikte hücre elde edilmesinde, kullanılan smear tekniğinin yanında, alınan smear'lerin boyanma yöntemi de büyük önem taşır. Rutin kullanım amaciyla seçilen boya türünün, hücreleri seçkin biçimde boyama özelliği yanında, kullanım kolaylığı sağlaması, uzun süre saklanabilir olması ve kalıcı preparatlar sağlayabilirliği açısından ideal olması gerekir (9).

Papanicolaou boyama tekniginin avantajları şunlardır (17): Epitel hücrcler ve eritrositler bu boya ile daha şeffaf görülür. Hücreler üst üste gelse de kolay ayırt edilebilirler. Lam üzerine alınan smear, kalın tabaka oluşturacak biçimde olsa da derinlemesine boyandıklarında ayırt edilebilirler. Asidofillik hücrelerin rengi kırmızıdan turuncuya kadar değişir. Bazofilik hücreler, yeşil veya mavi boya ahrlar. Bu durum smear tiplerinin kesin olarak tanınmasına yardım eder. Kana tutunmuş doku fragmanları veya hücreler, critrositlerin açıkça gözlenmesini engellese de, eritrositler karakteristik turuncu veya turuncu-yeşil renkte gözlenebilir. Kısmi veya tamamıla kurumuş olan preparatlar dahi, bu teknikle başarıh hiçimde boyanabilirler. Toluidine blue tekniği, kısa sürede boyama gercktiren smear'ler için kullanılabilir (5).

Bu çalışmada, değişik scksüel siklus evrelerinin ve gebeliğin iki farklı boyama yönteni kullanılarak saptanması ve bu boyama yöntemlerinin birbirlcriyle karşılaşınlması amaçlannışıı.

\section{Materyal ve Metot}

Araşurma materyali Gülhane Askeri ' $T_{\imath}$ p Akademisi'ne bağlı Deney Hayvanları Ünitesi'nden sağlanmış, çalışma ise Ankara Üniversitesi Veteriner Fakiiltesi. Doğum ve Jinekoloji Anabilim Dalı ،aboratuvarında yürütülmüştür. Araştırma materyali olarak 6-12 aylık, 220 - $250 \mathrm{~g}$ ağırlığında Spraquc - Dawley ırkı toplam 10 adet dişi rat kullanılmıştır.

Çalışma için seçilen ratlar, karma tip kafeslerde barındırılmış, bakım odasında 1 sı $21-23^{\circ} \mathrm{C}$ ve 1 şık/zaman ayan 14/10 saat olarak belirlenmiştir.

Dişi ratlar tek başlarına kafeslere konularak siklik takibe alınmışlardır. Takip edilen ratlardan 6-12 saat aralıklarla vaginal smear alınmış, sitolojik olarak östrusta oldugu saptanan dişi ratlarm kafeslerine 12 saat süreyle erkek rat bırakılmıştır.

Smear alınırken rat, kuyruk ve kuyruk kökünden tespit edilip kaldırılarak kafası aşağıya gelecek şekilde uıtulmuş, vagina \%:0.2 lik serum fizyolojik ile yıkandıktan sonra cam bagetle smear alınmıştır. Alınan smear örnek leri lam üzerine yaylarak, toluidine blue ve Papanicolaou boyama yöntemleriyle boyanmışur.

Toluidine blue boyama tekniğinde; hazırlanan preparat üzerine bir damla \%0.1'lik toluidine blue solusyonu damlatılmış ve beş dakika içinde kuruduktan sonra in. celenmeye alınmıştır.

Papanicolaou boyama tekniği ise yazarın (17) bildirdiği şekilde yapılmışır.

Vaginal sitolojik bulgular Schaberg (18)'in siklus değişimlerine bağlı olarak elde ettiği bulgular doğrultusunda değerlendirilmiştir.

Vaginal smear'lerde siklik değişiklik kriterleri, proöstrus evresi; başlangı̧̧ta intermedier hücreler ve evrenin sonuna doğru kornifiye hücrelerin, östrus; kornifikasyonun ve cozinofilik sitoplazmanın, metaöstrus; lö kositlerin, parabazal hücrelerin ve mukusun, yalancı gebelik; lökosit invazyonunun, gebelik ise; polimorfonükleer lökosit, mukus ve karakteristik olarak intermedier hücrelerin bulunnasına göre değerlendirilmiştir.

Preparatlar mikroskop altunda once küçük (10×20) daha sonra büyük büyütmede (10x40) incelenerek, siklus dönemine bağlı olarak hücre tiplerindeki değişiklikler ile gebelik dönemine özgü plaklann varlığ ve hücre değişikliklerinin smcar görünümü, farklı iki boyama yöntemi için kıyaslanmak suretiyle belirlenmiştir. 
Resimler faz kontras-ışı mikroskobuna (Nikon, Japonya) bağlı Nikon FX-35 DX fotograf makinası ve Nikon HFX-DXII ışık regülatörü kullanılarak çckilmiştir.

\section{Bulgular}

Çalışmada kullanılan ratlardan alınan smearlerden elde edilen sonuçlara göre seksüel siklusların dağılımı Şekil 1 'de şematize edilniştir.

Farklı siklus dönemlerinde hazırlanan frotilerde, özcllikle proöstrus döneminde başlayıp yavaşça artan ve östrusta belirginleşen sitoplazmaların pembe renk alma özellił̆i (asidofili), hijcre çekirdeklerinin seçilebilirliği, hiicre çcperlerinin boya alması gibi özellikler ile preparatların dayanıklılığı gibi kritcrler incelenmiştir (Şekil 2.3 ve 4 )

Söz konusu özelliklere ilişkin farklılıklar Tablo 1'de gösterilmiştir.

Siklus dönemlerinde her iki boyama yönteminde de saptanan hücre tipleri aynı olmakla birlikte, toluidine blue yöntemiyle yalnızca siklus evresinin tanımı yapılabilirken. hücrelerin daha iyi boya alma özelliğinc bağh olarak, Papanicolaou boyam. tekniğinde siklik evrenin kolaylıkla saptanmasından başka, hüicre oranlarma ilişkin bilgiler de elde edilebilmiştir (Tablo 2). Asidofili indeksinin, proöstrus döneminde \%20-30 iken östrusta $\% 90-95$ oranına yükseldiği ve bu oransal arışa paralel olarak keratinize süperfisiyal hücrelerin de arttı̆ ${ }_{1}$ saptanmıştır. Geç östrusta yeniden lökositler görülmeye başlanmıs ve intermediyer hücre oranının \%10-15 civarına yükseldiği saptanmıştır.

Gebelik, Papanicoloau yöntemiyle boyamadan sonra muköz plakların koyu yeşil renkte görïlmesi yoluylá saptanmışur. Bunun yanında, gebelik dönemine ilişkin sitolojik bulgu olarak yoğun lökosit infiltrasyonu (dejenere olmuş ve/veya olmamıs), intermediyer hücreler, az sayıda olmak kaydiyla parabazal ve keratinize huicre varlığ be lirlenmiştir. Toluidine blue boyana yönteminde sö\% ko

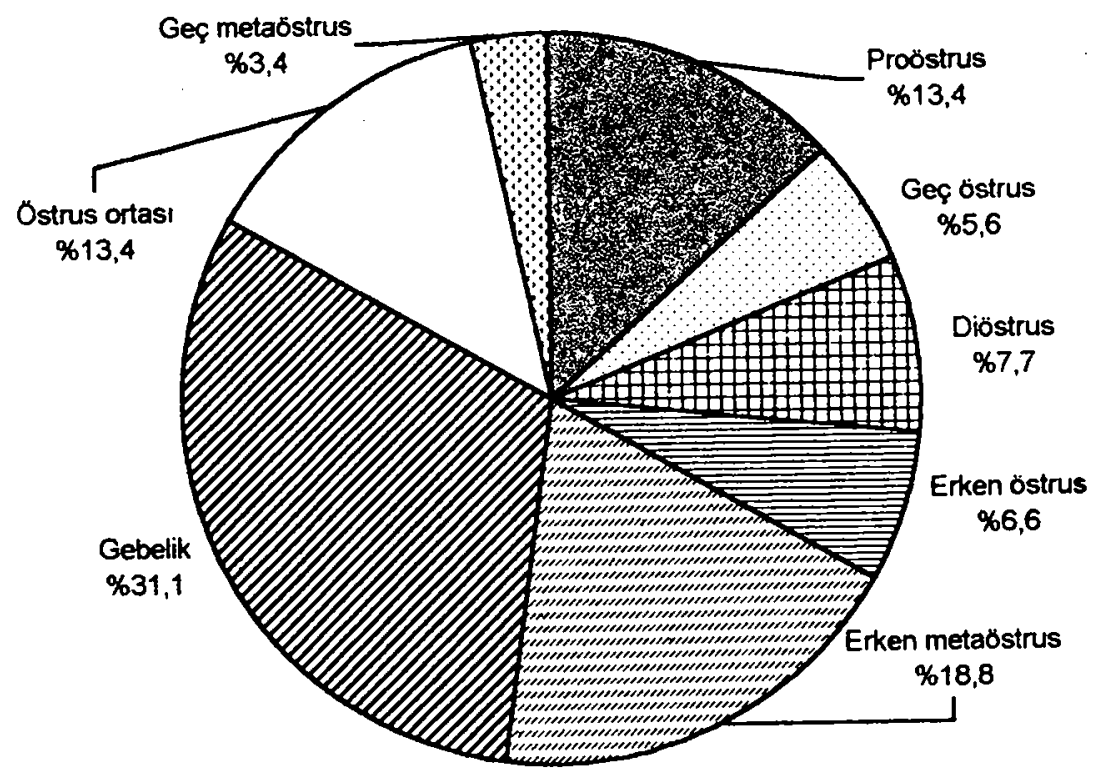

Şckil 1. Siklus dönemine göre vaginal smear örneklerinin dăğllımı.

Figure 1. Vaginal smear samples according to cyclic phases.

Tablo 1. Iki boyama yöntemi arasindaki farkhlıklar.

Table 1. Differences betwcen two staining methods.

\begin{tabular}{lcc}
\hline & \multicolumn{2}{c}{ Boyama yöntemi } \\
\cline { 2 - 3 } Hücresel özcllikler & Papanicolaou & Toluidine bluc \\
\hline Hücre çekirdeł̧ & +++ & + \\
Hücrclerin tanınması & +++ & ++ \\
Asidofili & +++ & - \\
Mukus & +++ & +++ \\
Lökositler & +++ & ++ \\
Keratinize hücrelerin seçilmesi & +++ & ++ \\
Sitoplazmanın boya alması & +++ & ++ \\
Hücre çcperlerinin boya alması & ++ & + \\
Preparatın saklanması & +++ & + \\
Hücrclcrin yiizdelcrin saptanabilmcsi & ++ & + \\
\hline
\end{tabular}




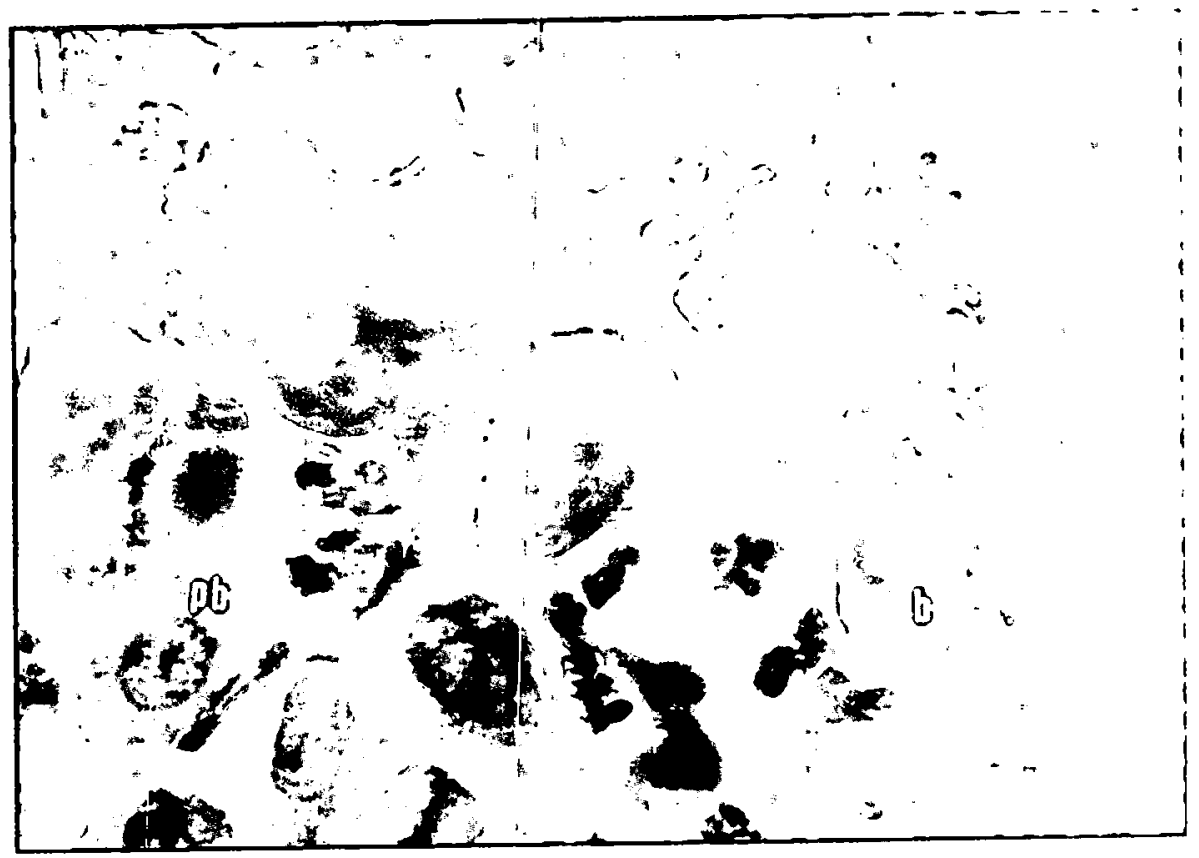

Sekil 2. Ratlarda Papanicolaou boyama yöntemi ile hazırlanmış vaginal smear hiicre görüntiisti. Figure 2. Vaginal cytologic cell images prepared with Papanicolaou stain ( I () 440$)$

b: Bazal hücre (basal cell) $\mathrm{Pb}$ : Parabazal hücre (parabasal cell)

k: Keratinize hücre (keratinised cell) pnl: Polimorf nuikleer lökosit (polymorphonuclear leucocytc)

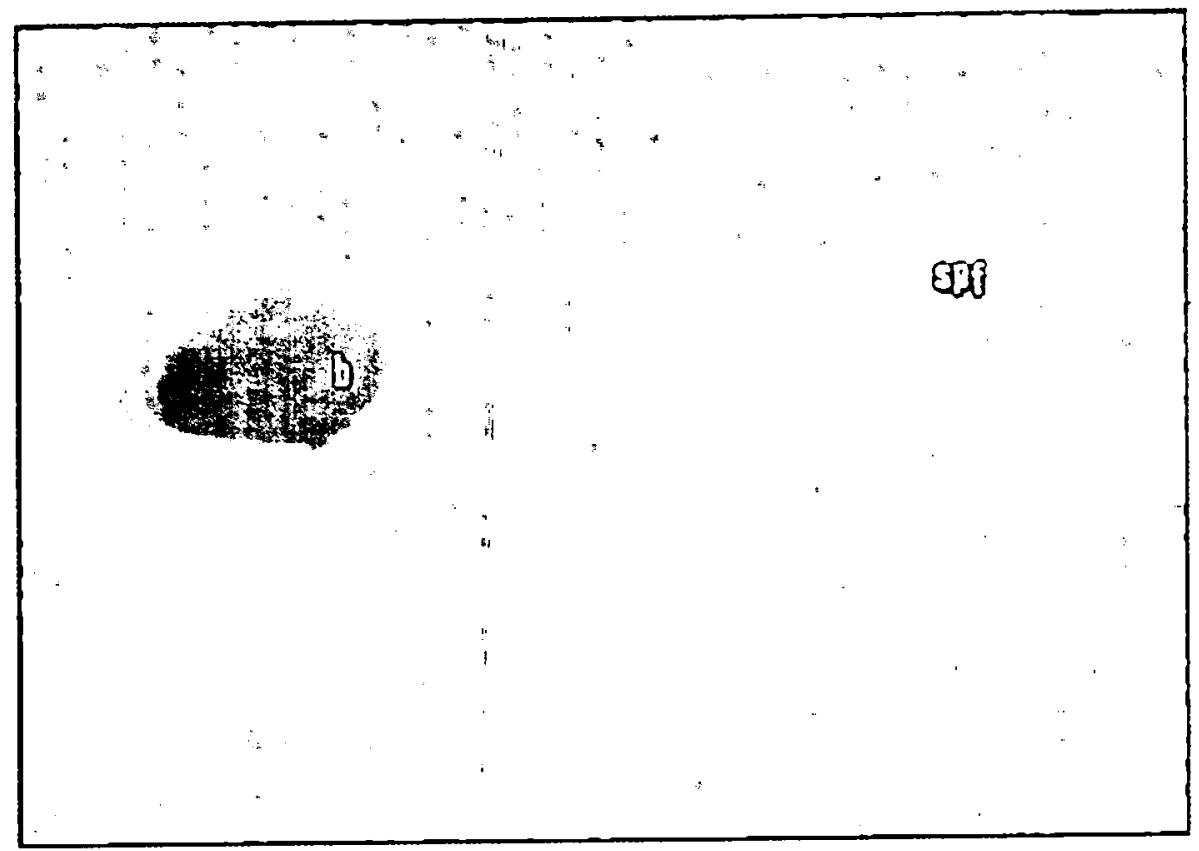

Şckil 3. Papanicoliou yöntemi ile boyanmış smear'de asjdofil ve bazofil ijzelliktcki huicreler $(1(1)+40)$. Figure 3. Acidophilic and basophilic cells prepared with Papanicolion stain (10)4(1)).
Spt: Siiperfisiyal (asidofilik) huicre
b: Baral (bazotilik) huicre
Spf: Supcrficial (acidophilic) cell
b: Basal (basophilic) cell

nusu plaklar knyu mavi renkte saptanmışur. Ayrıca, lökosil ve bazı kez bazal-parabazal hücreleri de seçmek müinküun olnuşstur.

Çalışmada ayrıca, hayvan gebe kalsa da, erken metäöstrus döneminde keratinize hücrelerin görülebileceğ gözlenmiştir. Mukusun rengine, yapısına ve hücre olu- şumlarına bakılarak gebelik tanısı konan 7 hayvanın 5 'inde (\%71.4) gebeliğin devam ctliği, ayrıca iki ratun diöstrüste bulunduğu $(\% 20)$ ve birinde siklus aktivilesinin duizensiz. olduğu saptanmıştır. Gebe olmayanlarda ise vaginal sitolojik takip ile 5-6 günlük periyot sonunda siklus aktivitesinin yeniden başladığ 


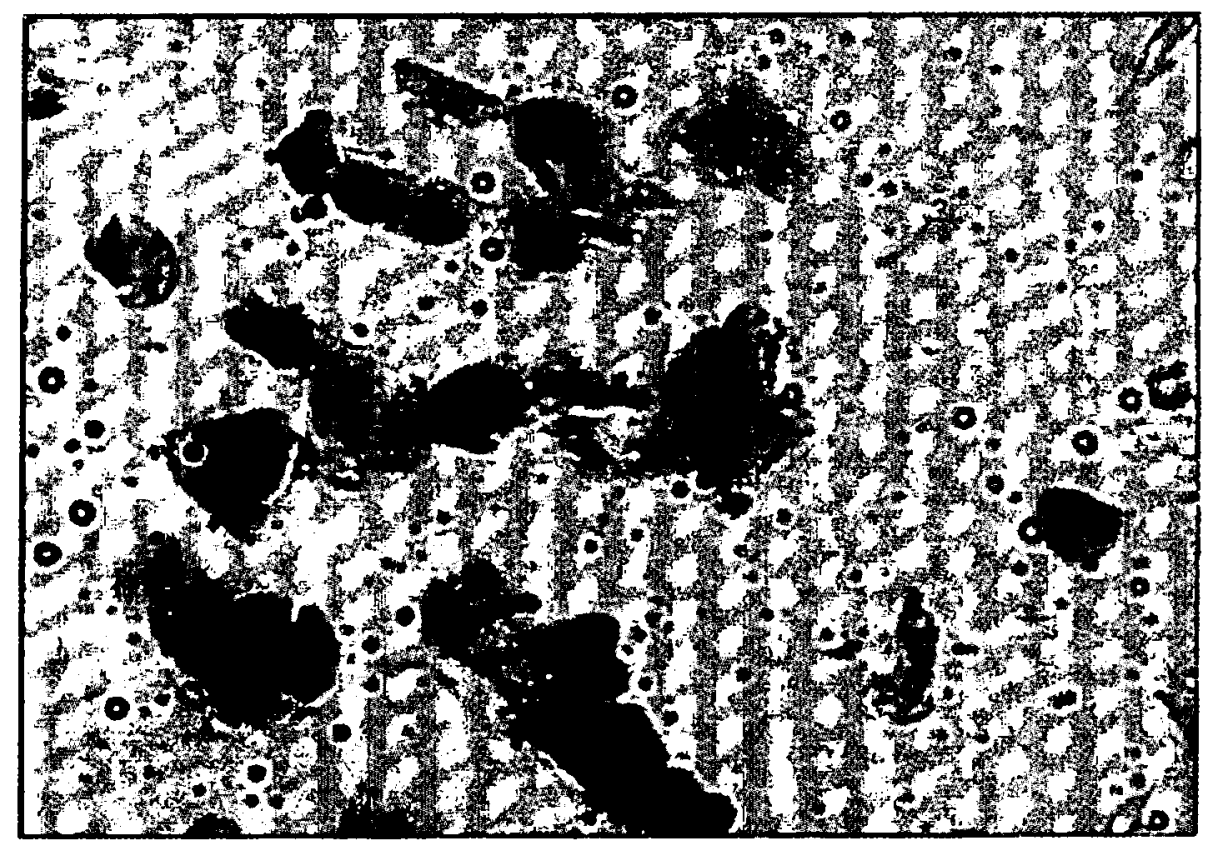

Sekil 4. Toluidine bluc boyama yöntemi ile hatzırlanmıs vaginal smear 'de proöstrus dönemine ait görüntii $(1() \times 10)$.

Figure 4. Procstrous cell images in vaginal smear stained with toludine blue method (10) 1(1)).

Tiblo 2. Rattarda siklus dönemlerine göre vaginal hüere dağlımı Table 2. Viaginal cells according to cyclic phases in rats.

\begin{tabular}{|c|c|c|}
\hline Siklus Döncmi & & \\
\hline Pron̈strus & $\begin{array}{l}\text { Intermediyer hücreler } \% 3(0-40 \\
\text { Parabazal ve bazal hücreler \%15-20) }\end{array}$ & $\begin{array}{l}\text { Cekirdckli sijperfisiyel hücreler \% }+(1) .5 .5 \\
\text { Asidofili \%2()-3(). lökositler }(++)\end{array}$ \\
\hline Frken östrus & $\begin{array}{l}\text { Kcratinize süperfisiyel hücreler } \% 60-75 \\
\text { Parabazal ve bazal hücreler } \% 10)\end{array}$ & $\begin{array}{l}\text { Çckirdekli siipcrfisiyel hucreler \%15-30) } \\
\text { Asidofili \%5()-60), lökositler (-) }\end{array}$ \\
\hline Ostrus & $\begin{array}{l}\text { Keratinize süperfisiyel hücreler } \% 80-100 \\
\text { Asidofili } \% 9()-95 . \text { likkositler }(-)\end{array}$ & Çekirdekli süperfisiycl hücrcler of ?()-() \\
\hline Geç istrus & $\begin{array}{l}\text { Keratinize süperfisiyel hücreler } \%(6)-70 \\
\text { Intermediyer hücreler } \% 15-30\end{array}$ & $\begin{array}{l}\text { Parabazal ve bazal hücreler \% } 1010-15 \\
\text { Asidofili } \% 70.75 . \text { lökositler }(+1\end{array}$ \\
\hline Erken melaöstrus & $\begin{array}{l}\text { Keratinize süperfisiyel hücreler } \% 7()-50 \\
\text { Intermediyer huicreler \% } \% 10-30 \\
\text { Polimorf nuklecr lökositler }(+)\end{array}$ & $\begin{array}{l}\text { Parabizal ve bazal hiucreler } \% 2(1)-40 \\
\text { Asidofili } \% 3(1)-35 \\
\text { Bitofili } \% 65-70\end{array}$ \\
\hline Geç melaöstrus & $\begin{array}{l}\text { Parabazal ve bazal hücreler } \% 75-85 \\
\text { Polimorf niiklecr lökositler }(++) \\
\text { Bazofili } \% 1(0)\end{array}$ & $\begin{array}{l}\text { Intermediyer hiicreler } \% 1,5-25 \\
\text { l.ökositlerde a\%alma }(+/-)\end{array}$ \\
\hline Diöscrus & $\begin{array}{l}\text { Parabazal ve batzal huicreler \%90-95 } \\
\text { Mukus ve lokosit }(++)\end{array}$ & Intermediyer hiicreler \%5-10. \\
\hline
\end{tabular}

asidolili ve yüzdeler Papanicolanu boyama teknị̣̌i için geçerlidir

\section{Tartışma ve Sonuç}

Ratlarda vaginal sitoloji bir çok çalışmada baş vurulan bir yöntemdir (7). Genel olarak ratlarda gebeliğin gerçekleşme oran $\% 75$ olarak bildirilmektedir. Ratlann birçok ke\% çiftleşmelerine karşın gebe kalmama olasılığı̆, vagumal sitoloji çahışnalarma önem kazandırmışur (25).

Sunulan çalı̧̧mada ratlarda seksiiel siklus dö nemlerinin ve gebeliğin vaginal smear yöntemi ile sap tanmasında 1oluidine blue ve Papanicolaou boyama yönıemleri kullanılmışır. Toluidine blue boyama yöntemiyle preparal 5 dakika gibi kısa bir sürede boyanabilmiştir. Ancak. söz konusu boyama yöntemiyle hücre çekirde- ğinin boyanması, hiicre çeperi ve sitoplalzmannn boya alması gibi, tanı açısındaan önemi olan özclliklcrin bckIentilere cevap verebilir düzeyde gerçckleşmediği gö. rülniusşür. Toluidine blue ile hazırlanmıs preparatlarda, hücre sitoplazma ve çeperleri, çekirdekler. hücre tipleri çok iyi seçilemediğ ve ayrıca asidofili ve bazofili aymmı yapılamadığı gözlennış̧tir.

Bu yöntemle siklus dönemlerini Tablo 2 de sunulau huicre tipleri doğrultusunda saptamak niimküin olmuşıur. Proöstrus, östrus, metaöstrus ve diöstrus dönemlerinin to luidine blue boyama yöntemiyle birbirinden ayrılabile. ceğini (22) bildirmişlerdir. 
Papanicolaou boyama yöntemiyle ise toluidine blue boyama yönteminin aksine, yukarıda sayılan ve seksuiel siklus dönemlerinin ayırt edilmesinde önemli olan bu ijzclliklerin en iyi şekilde seçilcbildiğ saptannışıtır. Bu boyama şeklinin ayrı bir avantajmın da hücrelerin, östrus döneminc yaklaşıkça asidofilik (kırmıวı-pembe renk) östrusun bitiniyle birlikte bazofilik (mavi-yeşil renk) renk almasınun saptanabilmesidir

Çeşiıli yay'mlarda birçok hılı vaginal smear boyama metodu. Papanicolanu boyama metodu ile karşlaşırılmuştır. Gencl olarak söz. konusu hızlı boyama yöntenlcrinde. siklik evrcye bağll olarak gelişen hornomal değişimlerin, preparata renk özelliği olarak yeterince yansımaması, hücre çeper ve çekirdeğinin yecrince hoya almaması gibi dezavantajları olduğu belirtilmiştir $(3.12,17)$.

Papanicolanu boyama yöntemi, bu sayılan özclliklerinden dolays vagginal sitoloji için standart bir boyamal yöntemi olarak kabul edilmektedir. Bu boyama yönteminin tek deravantajı 4()-60) dakika civarındaki boyama siiresidir $(1.3,6,12.21)$.

Ratlarda vaginal smear için elde edilen hücrelerin a\% olnass hücrelerin oranlarmın saptanmasını giiçleştirir. Boyama yöntemlerinin özelliğinden dolayı, bu araşurmada da Papanicolaou ile seksiiel siklus dönemine göre hiicrelerin yüzdelerj yaklaşık olarak olsa da saptanabilirken. toluidine blue ile hücrelere ilişkin herhangi bir yüzde elde edilnesi mümkün olmamışur. Bu yüzden, toluidine bluc boyana yöntemiyle yalnıca proöstrus, östrus. me laöstrus ve diöstrus dönenılerine ait hücre tipleri degerlendirilerek siklus dönemleri birbirinden ayrılabilmiştir. Geçiş dönenıleri ise ancak aym zamanda alınan Papanicolaou ile boyanan preparatlarla karşılaşurırılarak belirlenniştir. Çeşitli yaymlarda dört siklus dönemine (7.24) ve erken, geç metaöstrus dönentlerine ilişkin hücre tipleri tammlannışur. Bu çalışmada Papanicolaou boyama yöntemiyle östrusun erken ve geç dönemlerine ait olan hiicresel örcllikler de tanımlanmışur. Erken östrus döneminde \% 15-30 orannda olan asidofili indeksi, dönemin \% 10-15 civarmdaki bazal-parabazal ve \% $15-30 \mathrm{ci}-$ varmdaki intemediyer hiicrelerin görülmeye başladı ğ geç̧ östrus döneminden ayrılabilmesini olası kılmıştır. Ostrus dönemi Papanicolaou boyama yöntemine özgü asidotili indeksinin $\% 9(0-95$, keratinize süperfisiyel hücrelerin \%80-100 arasında saptanması ile erken ve geçöstrus dönemlerinden rahatlıkla ayrrlabilmiştir.

Muikio plakların. hoyama yöntemine bağlı olarak aldığ renk ve parçalı yapısına bağlı olarak gebelik tanısı konutan 7 raltan 5 'inde ( $\% 71.4)$ tanı, i\%leyen doğumlar ile doğrulanmış. diğger 2 ratta ise (\%28.6), daha sonra siklus aktivitesinin yeniden başladığ gözlenmiştir. Bu bulgu, ratlarda vaginal sitoloji aracılığ çckleştiğmin tan anlamıla orlaya konabileceği, ancak \$i\% komusu yöntemlc. konseptustan bir embriyonun gelişip gelişmediğgini belirleyemeyeceği gerf̧eğine dayandırılarak açıklanmakladır (25). Bunun yanunda rat- larda implantasyondan önce \%24.6. daha sonraki dönemlerde de \%12.2 oranında embriyonik kajıplarin şe killenebileceğgi de gö $z$ önünde tutulmalıdır (23). Iki ratın siklusun diöstrus evresinde bulunması, yalancı gehelik ile açılanabilir; zira vaginal smear'de diöstrus benzeri hulgular saptanması yalancı geheliğg ilişkin olabilmektedir $(13,14)$.

Gebelik saptanmayan diğer ratta ise. gözlenen siklus düzensizliğine bağh olarak. çiftleşme sonralsı gebelik oluşmadığı ve alınan örnekte mükör plak oluşumuna rastlanmadığ aksine hayvanm izleyen iį̣ giin boyunca. östrüs tablosu sergilediği saptanmıştır. Gerçekıen de yaşlı ratlarda siklik dïzensizliklerin. gençlere oranla dahal sik belirlendiğ i ve yaşin ilerlemesine bağlı olarak siklus sii resinde bazı uzamalarm olabileceği bildirilmektedir (1.3. 14).

Papanicolaou boyama yöntemi ile, farklı hücre lipIerinin diferensiyasyonu muimkün olurken, asidofil indeks ve keratinizasyon oranının belirlenebilmesine dayanularak prö̈strüs, östrus ve metaöstrus evreleri "erken" ve "geç" olarak dönemlere ayrılabilmiştir. Bunun yanında. asiçofili indeksinin belirlenehilmesi. Wayan östrus lamsmon konmasına yardınce olmuşurur.

Toluidine blue boyama yöntemi ile yalnz siklus cv. releri saptanırken, siklusun erken ve geç dönemleri ancak aynı anda alınan Papanicolaou boyama yöntemi ile karşılaştırılarak bulunnuşır

Gebelik dönemine ilişkin olarak iki boyama yönteminde de; luteal dönemin hücre karakıcristiğgimin vanında, müköz plaklarm varlığına dayanılarak. yiiksck hir doğrulukla tanı konabildiğ belirlenmiştir.

Ratlarda Papanicolaou boy'ama yöntemi kullanularak uygulanan vaginal sitoloji yöntemi ile. sağglılı hir siklik tan konabileceği ve gebeliğge ilişkin likir yuirittiilcbilece ğg sonucuna varılmışur

\section{Teşekkür}

Sitolojik de ğgerlendirmedeki kalkılartan dolayı saj 111 Dr.Nil Eriinal Maral a teşekkiir ederiz.

\section{Kaynaklar}

1. Aslan S, Erünal N, Kılıçoğlu Ç, Fındık M. Baştan $\Lambda$. Kaymaz M, Topaçlığlu S (1995): Einsatz der Papanicolaoula-farbemethode zur vaginalayologischen Untersuchung bei der Hündin. Ankara Unir Vel Falk Derg. 42. 431-439.

2. Bennet JT, Wickery BH (1970): Ruts and Mice 295-316. In: ESE Hatcz (Ed). Reproduction and Brecding Tech. niques for Laboratory Animals. Leil and Febiger. Phladclphia.

3. Brunner F (1983): Praxisnahe Schnellfarbemethoden :ur Vaginalivinlogie bei der Hïndin. Tierairal Prax. 11. 260. 277

4. Campean . V, Campean C, Rosenbauer KH (198(1): lixperimentelle untersuchungen zur frage der Va-

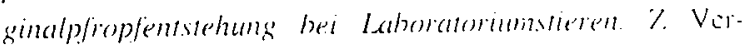
suchsticrkunde. 22. 50)-52. 
5. Christiansen IJJ (1984): Cyological examination of the vasinal smear. 20-28. In: IJ Christiansen (Ed). Reproduction in the Dog and Cat. Baillicre Tindall. London.

6. Christie DW, Bailcy JB, Bell ET (1972): Classificution of cell types in vaginal smears during the canine oestrus cwele. Br Vec J, 128. 301-309.

7. Cohrs R, Juffe R, Meessen H (1958): Pathologyie der Laboruroriumstiere. Springer-Verlag, Berlin.

S. Dennis F, Kohn SWB (1984): Laboratory Animal Medicine. Biology and Diseases of Rats. p. 91-120. Academic Press Inc Florida

9. Foldman CE (1987): Clinical Usefullness of Vaginal CytoIngy: Canine and Feline lindocrinology and Reproduction. p. 415-418. WB Sianders Co. Philadelphia

10. Freeman ME (1988): The Orarian Crcle of the Rat. The Physiology of Reproduction. Raven Press Lud. New York.

11. Havenaar R, Meijer JC, Morton DB (1993): Biology and Hashandry of Laboratory Animals. Principles of Laboratory Animal Science p. 17-75. Elsevier Co. Amsicrdim.

12. Kälin S, Hubler M, Casal M, Berger A, Kusch P (1987): V'uginalytologie bei der Hündin-vergleich verschiedener Fäbemethoden. Vaginalzytologie. Vct. 5, 13-15.

13. LeFevre J, McClintock MK (1988): Reproduction science in female rals. A longitudinal study of individual differences in estrous cycles and behavior. Biol Reprod, 38. 780)-789.

14. Lu KH, Hopper BR, Vargo TM, Yen SSC (1979): Chronolegical changes in sex stersid. sonadotropin and prolactin secretion in aging female rats displaying different reproductive states. Biol Reprod, 27. 193-203.

15. Mandl A, Zuckerman S (195()): The nunhers of normal and atretic ova immature rat. J Endocrinol (Oxford), 6. 426-435.

16. Montes (; S, Luque E $\mathbf{H}$ (1988): Effects of ovarian steroids on raginal smear in the rat. Acta Anat. 133, 192-199.
17. Papanicolaou GN (1942): A new procedere for stanin: vat ginal smears. SCI. 95, 438-439.

18. Schaberg ES (1992): Artificial intelligence in cutomnated classification of rat veaginal smear cells. Analyl Quans Cycol Histol, 14. 446-45i)

19. Scherer K (1993): Trächtigkeitsdiagnose bei Kaninchen Meerschweinchen und Ratte. 63-64. Ticrarall Prax. Sonderheft.

20. Schleyer D (1971): Zur makroskonpixchen und mikroskopischen anatomie des Genimaltrakts der weiblichen Albinorate. Aus dem Institut Histologic und Embryologec der tiere Universitat. Miinchen.

21. Tammer I, Blendinger K, Sobiraj A, Bostedt H (|yy4) Ober den einstaz der exfoliativen vasinalsybolesie in rahmen der ginikalogischen Befund-Erheloun:s bee der Handin. Tierärztl Prax. 22. 199-207.

22. Tekin N, Özyurt M, İzgür H (1980): Köppeklerde lec:smal smear vintemivle kizginltk siklusu evrelerinin tamist ias rinde f̧alssmalar. A Ü Vol Fak Derg. 33. $1982(19$

23. Werner J (1980): Pränctale Verlustraten and Finflut

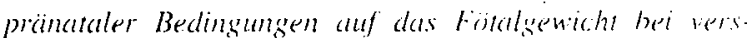
chiedenten Ratteninzucht-ind-hybridstionment. Medisintsche Hochschule. Diss. Hatnnover.

24. Yuan YD, RD Carlson (1987): Structure. Cretic Chamer and Function of Vagina and Vulva Rat. Genital Siskem. p) 161-168. Springer Verlag. Berlin.

25. Zacharias I. (1992): Versuche zur Zkiusdiagnostik und Brunstswnchronisation von keimfrei and komentionell gehaltenen Rentenweibchen. Ticrabaliche Hochashula. Diss Hinnover.

Yazışma adresi:

Prof.Dr.Selim Askm

Ankara Universitesi Veteriner Fakilles

Doğum ve Jinekoloji Anabilim Dalt

O6110 Diskal)!. Ankara

askan@veterinary.ankara.edu.tr 


\title{
Köpeklerde deneysel lamellar korneal oto- ve allogreft uygulamalari"
}

\author{
Perran GÖKÇE', 'Zülfikar SARI'TAŞ², Sait TONG' \\ 1 Ankitra Üniversitcsi. Veteriner Faküiltesi. Cerrahi Anabilim Dalı. Ankara: 2 Adnan Menderes Üniversitesi, Vetcriner Falkültesı. \\ Cerrahi Anabilim Dalı, Aydın
}

Özet: Bu çalışma ile otojenik ve allojenik lamellár keratoplastı uygulamalarının. özcllikle vecriner oftalmolojide korncal ülser. desconatosel, stromal apsc. kïçük korneal perforasyonlar. endotelial distrofi, skar dokusu olussumlaur gibi durum)larda klinik pratiğe sokulması amaçlandı. Çalışmada 12 adel melez köpek kullanıldı. Ü̧ gruba ayrılan bu köpeklerócn 4 üunde kilydırma yöntemi ile L.K (Brightman yöntemi-otogreft): 4 'inde trefin yardımı ile atlman greftin tekrar yerine ycrleştirilmesi ile L.K (otogreft): 4 'ïnde isc trefin yardım ile alınan korneaların birbirleri arasında yer değiştirmesi ile LK (allogreft) gerçekleştirildi. Postoperatif olariak 3 aly sürcyle izlenen olguların klinik muayencleri yapıld. Olguların hepsinde dikiş alımına kadar olan 45 gïnlijk süre içinde vaı külarizasyon. bazı olgularda odem olışumları izlendi. Birınci gruptaki bir olgu dış̧nda, dikiş alımını ve subkonjunktival steroid uygulamalarım izlcyen dönconde ise. bu bulguların ortadan kalktı̆̆ ve buittin greftlerin salydaın olduğg gözlendi. Alunin sonuçlar. urojenik ve allojenik greftlerin veteriner oftalmolojide rahatlıklat uygulanabileceğgini gösterdi.

Anahtar kelimeler: Keratoplasti, kornea, köpek, Jamellar. transplantisyon

\section{Experimental autogenous and allogenous lamellar corneal graft applications in dogs}

Summary: In this study, introducing of the autogenous and allogenous lamellar kcratoplasty applications (o) velerinary ophthatmology practice in our country in cases of corncal ulccr. descemetocele, stromal abscess, corneal perforation. cndothelial dystrophy and scar formation were objected. Twelve mongrel dogs were divided into 3 groups as autogenous LK with sliding met hod (Brightman incthod) in 4 dogs: autogenous LK with replacement of the trephined corneal grafts in 4 dogrs and allogenous $I$.K with interchanged corneal grafts between 2 dogs in 4 dogs. The donor tissue was sutured into recipient bed with interrupted ind continuc suture combination of $9 /($ ) and $1(0 /)$ nylon. They were observed for 3 months postoperatively. Si ne corncas had marked edemal of the grafted tissue and vascularization was developed during the first postsurgical weck. These vascularization and edema were resolved after suture removing and steroid administration subconjunctivally until 45 days, except 1 case in first group. These results showed that the autogenous and allogenous corneal grafts could be used in veterinary ophthalmology.

Key words: Cornea. dog, keratoplasty, lamellar, transplantition

\section{Giriş}

Kornea, bulbus oküili'nin en dıs katı olan fibröz ta. bakanın ışı̆ğn geçmesini ve kırılmasım sağlayan saydam kısmıdır. Aynı zamanda intraoküler yapılar için koruyucu fonksiyona sahiptir. Avasküler olan korncanın beslenmesi PTF (prekomeal tear film) ve humor aköz tarafından sağlanir.

Korneamı kalınlığı türlere ve irklara göre değjskenlik gösterir. Merkezdc $(0.61 \pm(0.01 \mathrm{~mm})$ periferden $(0.67 \pm 0.01 \mathrm{~mm})$ daha ince olan kanin korncasının kalınlığ 409-784 $\mu \mathrm{m}$ arasında; vertikal uzunluğu 12-16 mm, horizontal uzunluğu $13-17 \mathrm{~mm}$ arasında değişkenlik göstcrir $(6,8)$.

Korneada oluşan patolojik olguların klinik önemine göre ödem, vaskuilarizasyon, skar dokusu oluşumu, pigmentasyon gibi bir takım reaksiyonlar şekillenir. Olgunun şiddetine göre, bu reaksiyonlardan sadece biri gözlenebileceği gibi, birkaçı da bir arada olabilir (6).

Keratoplasti, cerrahi yöntemler kullanarak hasarlı knrnea' nın yerine, sağlıklı kornea yerleştirilmesidir. Kor- neal greftler, ilk kez 1824 yllnda oftalmik literatiurlere girmekle birlikte, 1900 'lü yıllara kadar pratik önemi olan teknikler geliştirilememiştir $(1,3.8)$. Son 20) yılda isc, özellikle insanlarda korneal grefı tcknikleri çok başarılı sonuçlar alınacak şckilde gelişme göstemmiştir.

Veteriner oftalmik cerrahide ise, tavşanlar, kediler ve diğer hayvanlarda oldukça farla dencyscl çalışma yapılmasına karşın, korneal greftlcrin klinik uygulamasına ilişkin çok az rapor bulunmakıadır ve bałı seçilmış durumlar dışında çok geniş bir'uygulama alamma sahip değildir $(1,6,7)$. Genellikle vet"riner oftalmolojicte optikal. rekonstrüktif, terapötik ve kozmetik amaçlarla kullamılan korncal transplantlar, Slatter (6)'e göre yalnuzca hilateral göruş zorlự̆u ya da kaybı olan hay'vanlardia duişiinuilmelidir: ayruca. derin korneal iilser, desemetosel. korncal stromal apse, küçük korncal perforasyon, endolclial distrofi veya dejenerasyon, korneal neoplazi ve ciddi aksial korneal opasitc gibi. konjunktival greft veyal keratcktomi gibi sağalımlara kolayca yanı verebilen durumlarda da.

Bu araştırma TUBITAK tarafindan destekjenen VHAG-1326/ADP no'lu ayn adlı projeden öıetlenmiştir.

Ankara Üniversitesi, Veteriner Fakiiltesi Etık Kurul Onayı alınmışur 